Portland State University

PDXScholar

\title{
Gentrification and Student Achievement: a Quantitative Analysis of Student Performance on Standardized Tests in Portland's Gentrifying Neighborhoods
}

Justin Joseph Ward Portland State University

Follow this and additional works at: https://pdxscholar.library.pdx.edu/open_access_etds

Part of the Elementary Education Commons, and the Urban Studies and Planning Commons Let us know how access to this document benefits you.

\section{Recommended Citation}

Ward, Justin Joseph, "Gentrification and Student Achievement: a Quantitative Analysis of Student Performance on Standardized Tests in Portland's Gentrifying Neighborhoods" (2019). Dissertations and Theses. Paper 4867.

https://doi.org/10.15760/etd.6743

This Thesis is brought to you for free and open access. It has been accepted for inclusion in Dissertations and Theses by an authorized administrator of PDXScholar. Please contact us if we can make this document more accessible: pdxscholar@pdx.edu. 
Gentrification and Student Achievement: A Quantitative Analysis of Student Performance on Standardized Tests in Portland's Gentrifying Neighborhoods

\title{
by
}

Justin Joseph Ward

A thesis submitted in partial fulfillment of the

Requirements for the degree of

\author{
Master of Urban Studies \\ in \\ Urban Studies \\ Thesis Committee \\ Lisa Bates, Chair \\ Michael Smith \\ Liming Wang
}

Portland State University

2019 


\begin{abstract}
Across the United States one would be hard pressed to find an urban center that has been unaffected by the phenomenon known as gentrification. From substantial economic growth to the displacement of long-term residents, the benefits and criticisms of the process of gentrification are wide ranging and extend over a thorough body of literature. Commonly associated with increasing levels of education and higher resident incomes, gentrification should be a boon to struggling public schools that are continually plagued by generational poverty. Unfortunately, the continued widening of the education gap and increasing racial segregation in our public schools (G. J. Duncan \& Murnane, 2014) suggest that any benefits of gentrification are not translating to equity in our public schools. By looking at the city of Portland, this paper attempts to quantitatively explore the complicated relationship among gentrifying neighborhoods, school performance on the $3^{\text {rd }}$ grade standardized Math and Reading tests, and racial demographics of the students. This paper will follow the methods established by Keels et al. in their work on gentrification and school achievement in Chicago (2013). By using 2000 Census and the 2015 ACS data and spatial analysis and mapping in GIS, gentrifying school neighborhoods in Portland will be identified and analysis of student test performance and racial demographics will be conducted to determine if any relationship exists. By exploring how these schools have changed both academically and racially we can expand educational and urban theory around the process of gentrification.
\end{abstract}




\section{TABLE OF CONTENTS}

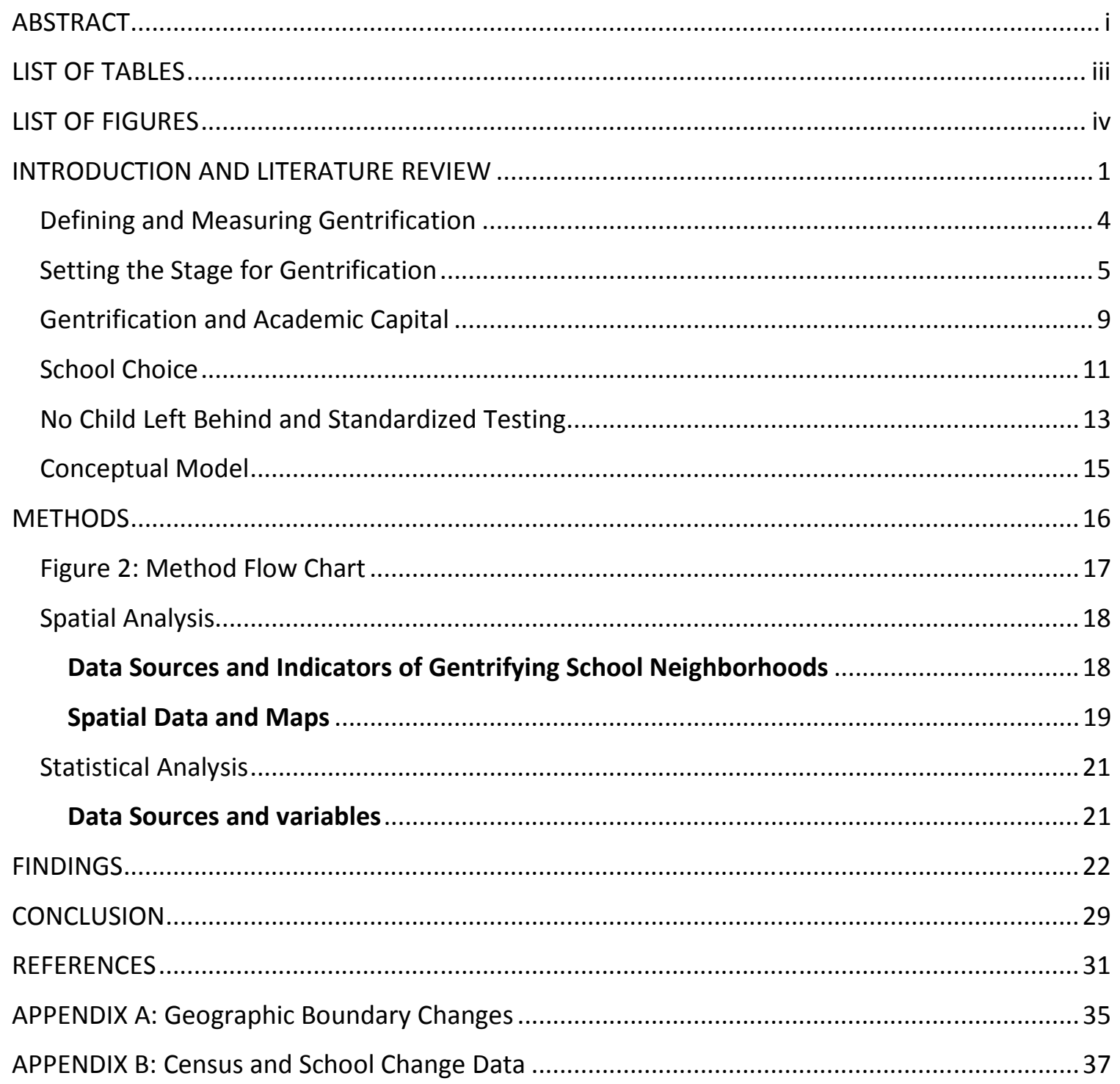




\section{LIST OF TABLES}

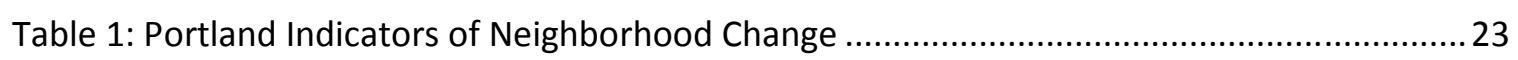

Table 2: Performance on Standardized Tests by Neighborhood Type (2000-15) .........................27

Table 3: Change in Performance on OAKS: Gentrifying vs. Stable Neighborhoods.......................28 


\section{LIST OF FIGURES}

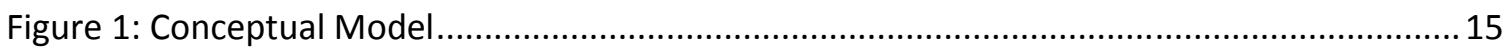

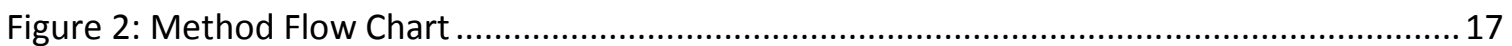

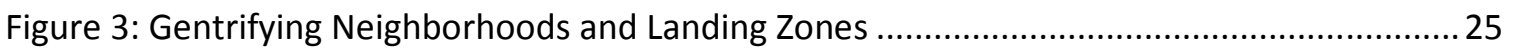

Figure 4: Stable/constant Schools vs. Gentrifying School - Math............................................... 26

Figure 3: Stable/constant Schools vs. Gentrifying School - Reading .......................................... 26 


\section{INTRODUCTION AND LITERATURE REVIEW}

In the last half-century, urban revitalization efforts in city centers have attracted suburban middle-class residents back to the city with the cost of displacing low-income, and often minority, residents to the fringes. This "urban revitalization" or "urban redevelopment" is a rebranding of gentrification, in order to allow planners and city developers to distance themselves from the negative impacts that are historically synonymous with gentrification (Slater, 2013). Despite the displacement and cultural dispossession associated with gentrification (Harding \& Blokland, 2014), advocates for gentrification cite the development of local services and amenities as a result of the influx of social, cultural, and economic capital that follows gentrifiers (Freeman \& Braconi, 2004; McKinnish, Walsh, \& Kirk White, 2010; Vigdor, 2002). As resources and economic capital relocate to traditionally disinvested regions of a city a question arises, what effect if any does this have on our local public schools? The focus of this research aims to answer whether gentrification has influenced student academic outcomes in Portland's public elementary schools? If so, in what ways?

Nationwide, our urban K-12 public schools are plagued with low attendance and graduation rates (Balfanz, Herzog, \& Mac Iver, 2007; Catterall, 1987; Rumberger, 2001), high levels of crime and student dropout rates (Chen, 2008), and a long history of unsatisfactory test scores amongst students from low-income families and students of color (Coleman, 1988; EOGOAC, 2015; Farkas, 2008; Sandy, Duncan, \& Cede, 2010). The stark disparity 
between our suburban and urban schools, high-income and low-income students, and white and black students has raised questions of systemic inequity in our current education system. While the relationship between social class and education attainment has been well understood and documented, the status quo appears to continuously be reinforcing this divide. In a society that is increasingly mobile, it is necessary for city planners, policy makers, and education specialists to understand how these instances of neighborhood change can transform our public schools.

By using the city of Portland as a unit of analysis, this research will investigate the measurable effects of gentrification on student academic outcomes. Only a few notable and similar studies, like the one conducted by Keels et al. (2013) in Chicago, have been done to quantitatively measure this relationship. While many researchers have theorized about this relationship and academics like DeSena (2006 \& 2009), Cucchiara (2008), and Silverman (2014) have written extensively on this subject, there still seems to be a gap in the available research that documents a quantitative correlation between these changing neighborhoods and public schools. This study aims to add some understanding to that gap

With the growing awareness of the phenomenon of gentrification, it is important that we expand our understanding about the effect gentrification has on education outcomes. The dualism of gentrification as a process of displacement, disruption of social capital, and cultural dispossession as well as a process of investment, improving safety, and economic 
growth have been well documented (Slater, 2006), and critiques or challenges on all of these claims have been made numerous times.

Although research on gentrification has been extensive, especially in the past couple decades, there is a surprising lack of research on its effect on local public schools (Jordan \& Gallagher, 2014; Silverman, 2014; Warren, 2005). A better understanding of this relationship is important for city planners and education policy makers to anticipate any influence gentrification might have on community public schools. While at one time it has been argued that, community builders and school reformers act as if urban schools and communities are not linked (Warren, 2005), the growing work of local organizations like SUN community schools, STAND for children, and the Multnomah Youth Commission serve as examples that this is not necessarily the case in Portland. However, what is still missing is an understanding of the measurable effects that communities have on schools. While a complete understanding of this relationship is incredibly complex, this paper will attempt to uncover the quantitative and measurable change the process of gentrification has on school demographics and performance on standardized tests by $3^{\text {rd }}$ grade students. If we are to continue to think of education as one of the great indicators of social mobility it is necessary for community builders, policy makers, and education reformers to understand the direct effect that the process of gentrification has on local public schools. 


\section{Defining and Measuring Gentrification}

Gentrification can be understood as an influx of residential and commercial investments in previously disinvested urban neighborhoods, followed by the arrival of higher socioeconomic households with the cost of displacing low-income households from the neighborhood. As explained by Smith, "It is this combination of social, physical, and economic change that distinguishes gentrification as an identifiable process" (1987, pg. 463). However, to apply this universally is not particularly easy. As pointed out by many, the discussion on this topic is long and conflicted (Bates, 2013; Redfern, 2003; N. Smith, 1987). The interpretation and definition of gentrification is continually amended and redefined throughout the expansive literature on this topic. This is largely due to gentrification not being a discreet event or observation, but rather a process that extends over time and transforms based on the context of the city or communities it is manifesting in. According to Tom Slater we need to get away from the obsession of redefining gentrification and instead place greater efforts on understanding the underlying causes and theories that explain gentrification as a process (2013). In the years since Slater aired this grievance, it seems that the literature on gentrification as indeed come a long way.

Instead of wading into the murky process of defining gentrification this study relies on established literature to identify instances of gentrification across the city of Portland. Spatially, gentrification can be identified by increasing rental prices or home values, increased income through a substantial shift to white collar employment, and an increase 
in the population of residents that hold a four year degree or higher, improve local amenities, and racial demographic change (Ley, 1986; Patrick Heidkamp \& Lucas, 2006; Wyly \& Hammel, 1998). For the purposes of this study I will be using the four variables for measuring and identifying gentrification: (a) Household Income-Perhaps the most notable variable associated with gentrification is the arrival of new wealth into a gentrifying neighborhood. In a 1990-2000 study, national census data determined that gentrifying neighborhoods experienced an average median household income increase of over $\$ 10,000$ (McKinnish et al., 2010; Zuk et al., 2015). (b) Home Value-Because revitalization of housing and creation of mixed income developments are typically the most outwardly noticeable characteristics of a gentrifying neighborhood (Slater, 2013; Sullivan, 2007). (c) Higher Levels of Education-Because of its close correlation with social class, levels of education is commonly used to identify areas that are becoming more affluent (Freeman \& Braconi, 2004; Ley, 1986; Sullivan, 2007; Zuk et al., 2015). (d) Change in Racial Demographics - deeming displacement a necessary part of gentrification it is imperative that this study look at the change in racial demographics in neighborhoods to create a robust method of identifying gentrification.

\section{Setting the Stage for Gentrification}

Gentrification is not an accidental process that manifests in random neighborhoods or cities. Instead, like most urban phenomena it was created through practices facilitated by urban politics and structural systems. Things like: Neighborhood ghettoization, redlining, 
discriminatory housing practices, and predatory banking are a few are of the more prominent causes that create conditions ripe for gentrification.

Ghettoization: Deep rooted racism and a strong desire of the affluent to protect their property values, ghettos were formally and informally created through local housing policies to centralize poverty and minorities in order to geographically maintain a class divide. Black and minority communities in Portland were further marginalized and stigmatized by the crime and vice that was purposefully ignored by law enforcement and allowed to prosper in neighborhoods like Albina (Serbulo \& Gibson, 2013). This stigmatization can have destabilizing effects on these communities that further marginalize the occupants and subject them to further discriminatory actions and justify purposeful neglection and divestment through redlining (Wacquant, 2007). By centralizing poverty in urban ghettos and once severe spatial stigmatization was accomplished, urban society and outsiders could use them as dens of vice without fear of the negative externalities associated with such behavior rolling over into their own communities. If this kind of illicit behavior could be eradicated it was simply easier to gain control by encouraging it in the ghettos so that it was contained, without care to the way this pathway to control negatively disrupted health, education, safety, and general livelihood of those trapped in the ghetto.

Redlining: Motivated by capitalistic interests, redlining is the process in which investors and banks adopt guidelines that deny funding in the form of loans for investment in urban areas that are experiencing economic decline (Byrne, 2003). Because economic capital and 
ethnicity are so closely related, redlining was as much a deprivation of resources for the poor as it was for minority communities. In their study on Portland, Serbulo and Gibson determined that redlining was not merely motivated by invisible motivators, but was intentional and an established guideline for lenders and investors to follow (2013). The withholding of public and private funds from impoverished neighborhoods magnified problems of education, violence, and drug use that are typically found in areas of extreme poverty. Redlining, especially in Portland's Albina, Alberta, and Chinatown neighborhoods formally separated residents in these areas from economic capital and social mobility.

Discriminatory Housing in Portland: A history of overt and institutionalized racism permeated Portland so thoroughly that until 1956 Portland realtors followed a National Realtors Code which stated, "A Realtor should never be instrumental in introducing into a neighborhood a character of property or occupancy, members of any race or nationality, or any individuals whose presence will clearly be detrimental to property values in that neighborhood.” Even into the 1960 's it was generally understood that $90 \%$ of realtors still would not sell a home to a black individual or family in a white neighborhood (Gibson, 2007). Historically minority residents of Portland have not only faced difficulties acquiring fair loans, but they were restricted from living in certain many neighborhoods, thus creating city sponsored segregation and further intensifying the concentration of poverty. 
Predatory banking practices: Although banking institutions have been guilty of predatory practices for generations (and many would argue since their inception), we saw in the 2007 market crash how these practices are targeted toward low-income communities and communities of color (Davidson \& Martin, 2014). Amongst many other dishonest policies, substandard loans were disproportionately extended to low-income borrowers that had much higher chances of defaulting on the loans. As we saw this had a devastating effect on our global economy as well as those that were victimized by these practices. Relaxed regulation of banking under neoliberal reforms allowed for private banking institutions to take advantage of and profit from the already precarious financial positions of many of these communities.

While many of these practices are restricted by the 1968 Fair Housing Act, an inability or unwillingness to enforce these laws prevented that state from effectively regulating these kinds of behaviors (Lipsitz, 1994). These practices have helped set the stage for gentrification in urban centers like Portland across the country by collectively contributing to the further depreciation of land value in areas of concentrated poverty. This depreciation of value, especially of land that is centrally located creates what is known as a bid rent gap, which is a difference between the lands current value and its potential value (Anas, Arnott, \& Small, 1998). It is this gap between the actual and potential value of land, that creates a market ripe for gentrification. In his theory of gentrification, Neil Smith argues that gentrification is primarily motivated by capital gains, through investment in the housing market (1979). When a large rent gap appears gentry and other outside investors are 
motivated by capital gains to move into the area. This ultimately serves two ends, first it transforms these areas into a neighborhood that meets the wants of those with the capital (the gentry), second it quickly drives up the land value which can force long term residents from their homes and neighborhoods. The cost of redevelopment and revitalization in gentrifying neighborhoods is felt disproportionately on the lower income and minority residents as they are often priced out of these neighborhoods(Defilippis \& Fraser, 2010; Slater, 2013; A. Smith \& Timar, 2010; N. Smith, 1979), and those that are able to remain often lack the social capital to participate in the changing community the way they once might have (Lees, 2008).

\section{Gentrification and Academic Capital}

There is a rich base of research that connects high academic achievement to many of the characteristics of families that participate as gentry. In this way gentry bring a kind of academic capital to their new neighborhoods. This academic capital is a combination of economic, human, and social capital that all have positive relationships with student academic achievement and performance on standardized tests.

Perhaps the most commonly understood connection, is the overwhelming influence that family income plays on a student's academic achievement. From Early childhood education to higher education, several scholars give a thorough overview of the many ways in which socio-economic background can dictate their academic success (Coleman et al., 
1966; G. Duncan \& Murnane, 2011). Education and income are so closely linked that it comes as no surprise that the widening education gap is closely mirroring that of the income gap. The education gap has been growing for the past fifty years and it was found that, "The achievement gap between children from high- and low-income families is roughly 30 to 40 percent larger among children born in 2001 than among those born twenty-five years earlier" (Reardon, 2011). Given an understanding of this relationship, some have argued that the promise of a mixed or higher-income neighborhood would be a boon for struggling and traditionally low-income school (Byrne, 2003).

Literature also argues for the direct connection between academic pedigree and student achievement. Higher levels of parental education is directly connected to lower student dropout rates (Rumberger, 2001), as well as child hood brain development, early skills development, and educational attainment (Davis-Kean, 2005; G. Duncan \& Murnane, 2011). In his study of the widening education gap, Sean Reardon found that parental education was a much more powerful indicator of student academic achievement than income (2011).

When controlling for both socio-economic and educational backgrounds, there still seems to be yet another indicator of student success: ethnicity. Biased tests, white cultural norms, and systemic racism further disadvantage minority students in our educational system. Even when controlling for things like income, it has been argued by some that minority students still tend to perform worse academically and are disciplined more frequently than 
their white peers (Gregory, Skiba, \& Noguera, 2010). This suggests that as neighborhoods become whiter and we might expect to see an increase in standardized test performance because teaching styles and tests are carried out and written with a white bias.

With education theory supporting the claim that the human, social, and economic capital associated with the gentry should have a net benefit to our local public school, what I plan on investigating is how great are these benefits? The displacement and loss of social control that low-income and minority residents face is too great a cost. This research is proposing to understand if those residents that do stay in these changing neighborhoods are benefitting from improved public school? Unfortunately, according to education scholars and school choice scholars this may not be the case where public education is concerned (Davis \& Oakley, 2013; Desena, 2006; Desena \& Ansalone, 2009; Jordan \& Gallagher, 2014; Lipman, 2008). If high academic achievement has long been associated with the higher income and levels of education why might gentrification be failing our public schools?

\section{School Choice}

Good Schools are real estate anchors in gentrifying communities (Lipman, 2004). The promise of a great education is a strong motivation for medium and high-income parents to relocate and stay in gentrifying neighborhoods. Unfortunately, the investments in schools seem to be made largely in charter and private schools rather than our public schools. While top performing schools have been theorized to be agents of gentrification, 
these schools are rarely public and oftentimes don't serve a population that is representative of the larger neighborhood. In her analysis of school attendance behavior Judith Desena, examines the many ways in which gentry families participate with the education system and matriculate their students (Desena, 2006). Perhaps most importantly she argues that local schools are often rejected by gentry (2006, pg. 248). Instead of participating in local schools Desena, reports that the wealthier families take advantage of their mobility and send students out of district to a better school, or enroll their students in private schools. This kind of attendance behavior can be incredibly important in Portland because of the freedom of inter-district and school transfer afforded by Oregon law (HB 3681, 2012). One problem that struggling public school face as a result of this attendance flexibility is the loss of revenue, "Every student who leaves, takes along at least $\$ 5,000$ in state funding" (Owen, 2011).

Amongst gentry parents that do participate with local public schools, Desena reports that they are able to use their social or economic capital to leverage the schools to serve their needs (2006). While this may be ultimately beneficial to the school and not directly harm long term residents, there is a worry that this behavior further distances minority and low-income families from having a voice in school decisions. This research does not seek to make an argument for or against school choice, rather it simply intends to discuss and investigate the possible challenges that school choice presents for neighborhood public schools and the possible role they may play in spurring gentrification. 


\section{No Child Left Behind and Standardized Testing}

While testing has been established as the standard for measuring student academic performance of scale, it has also been criticized for a number of limitations and inherent biases (Vargyas \& Connor, 2013). The cultural, gender, and language bias in these tests have been well documented, and research suggests an inherent disadvantage for those that speak English as a second language or those that don't easily identify with mainstream white culture. In his discussion on alternatives to traditional testing, Howard Gardner argues that we have moved away from apprenticeship style assessment and fully embraced and completely validated the more formal style of testing that we have become so familiar with in our schools (Gardner, 1992). While always a standard of evaluation in our education system, testing took on an entirely more substantial role in our education with the passage with No Child Left Behind (NCLB) act of 2001.

NCLB is widely considered to be the most far reaching education policy since the 1970's (Dee \& Jacob, 2010). NCLB's most drastic feature was connecting testing performance and yearly progress of students to federal and state dollars. It required States to conduct annual assessments that measured a student's yearly progress and grant rewards or implement sanctions on districts based on the yearly progress of tested students. If testing had been a substantial part of our education system before, it was placed squarely at the heart of it with the passage of NCLB. By threatening funding and potential resources, NCLB forced schools to prioritize testing in a way that was never previously done. With the passage of Every Student Succeeds Act (ESSA) our schools might see a shift away 
from this prioritization of testing, but for the time being testing continues to be the standard by which we measure student growth.

Other measures, such as GPA, attendance, discipline, and graduation rate are less reliable because they are not all measured consistently across class rooms or schools. Standardized testing is a uniform test that allows for a more normative comparison of student performance across schools, cities, and counties. Because testing has, and will most likely continue to be, the standard by which we measure student success, this paper will rely on the Oregon Assessment of Knowledge and Skills (OAKS) as the best metric for student growth. 


\section{Conceptual Model}

The purpose of this thesis is to conduct a Quantitative exploration of the relationship between changing school neighborhoods and school test performance and racial demographics. Below is a conceptual model used to connect established urban and education theory to my research design.

\section{Figure 1: Conceptual Model}

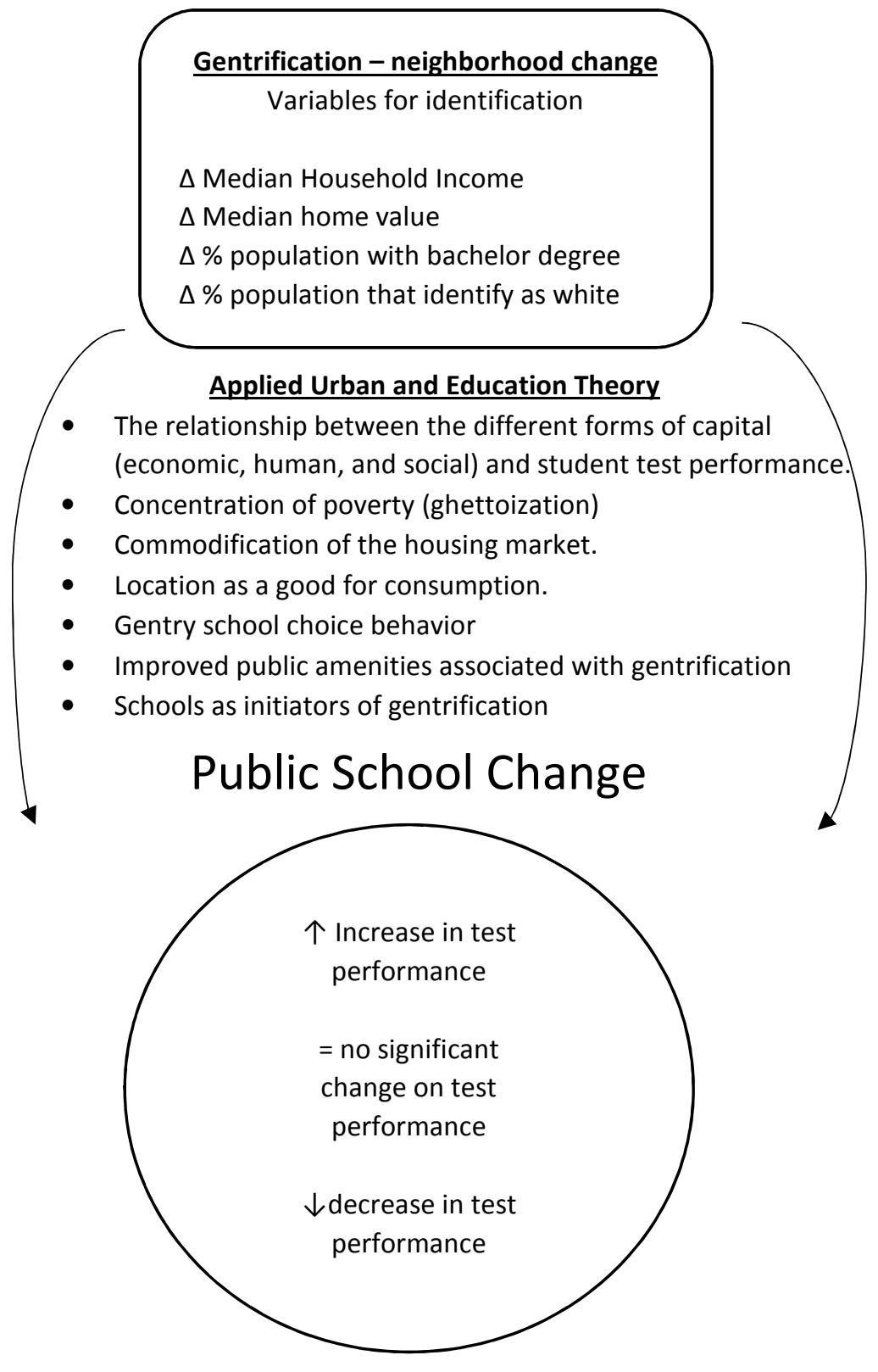




\section{METHODS}

The research necessary for the completion of this thesis was broken into two distinct parts. The first part is a spatial analysis component that identified gentrifying school neighborhoods in the city of Portland. The second part was a quantitative analysis of student test scores in the identified gentrifying neighborhoods.

Because this thesis is meant to add to the limited but growing amount of literature on this topic, rather than reinvent the wheel, this research will be relying heavily on research methods that have come before. The methods in this study will closely mirror those used by Keels et al. in their paper "The Effects of Gentrification of Neighborhood Public Schools" (2013). Because this paper will be using Portland neighborhoods as the unit of analysis rather than Chicago, there will be adjustments made to the methods to account for

these very different contexts. Refer to fig. 1 for a flow chart that outlines the steps intended for this study. 


\section{Figure 2: Method Flow Chart}

Use Portland as a baseline by establishing percent change between 2000-2015 in the following indicators:

- Median household income

- Median house value

- Population 25 years and over with a Bachelor's degree
Note: Pre-data will come from the 2000 Census and post-data will come from 2015 5-year ACS
Establish percent change, in same variable as above, between $2000-2015$ by census tract
Using ArcGIS find the mean of the percent change of the census tracts in each school catchment zone. This will give me an approximate percent change in the indicators of gentrification by school neighborhood.
Compare school catchment area change to the baseline change. Catchment areas with variables that demonstrate a percent change greater than the baseline change are treated as indicators of possible gentrification

School catchment areas that exceed the baseline change in all 4 of the indicators of gentrification will be labeled as "likely gentrifying."
Note: School catchment zones that have changed dramatically and have completely changed the geographic area they serve will be excluded from this analysis.
Note: "likely gentrifying" areas are places that demonstrate characteristics that suggest they might have gentrified or were likely gentrifying during the 2000-2015 period, these areas will denote the schools of interest for this study

After establishing schools that reside in neighborhoods that are "likely gentrifying," determine academic

growth or decline in student performance on the $3^{\text {rd }}$ grade standardized reading and math tests

Note: Data will come from the Oregon Department of Education

Note: Data PPS enrollment profiles

Statistical analyses: To be determined upon review of preliminary findings. 


\section{Spatial Analysis}

First, a spatial analysis was conducted using census data to interpolate census tract data onto Portland's public-school attendance areas. To do this, a comparison between 2000 and 2015 census tract data was used to determine gentrifying neighborhoods around Portland elementary public schools. For the purposes of this research, education, housing value, income, and racial demographic change were used as the variables to identify gentrifying communities. The variation in changes of these four indicators indicated varying degrees of gentrifying school neighborhoods. The changes in these variables were then mapped to school catchment areas to give us an idea of the change in the school neighborhood.

\section{Data Sources and Indicators of Gentrifying School Neighborhoods}

1. 2000 Decennial Census tract data

2. 2015 ACS Census tract data

Indicator 1: Change in Median household income

Indicator 2: Change in Median house value

Indicator 3: Change in Population 25 years and over with a Bachelor's degree Indicator 4: Change in Percent of population identified as non-Hispanic white

To establish a baseline, percent change between these variables from 2000 through 2015 will be done on Portland citywide. Portland served as the baseline score to be used in comparison to the change between the variables on the census tract level. Possible gentrification will be indicated if the percent change in the indicators on the school neighborhood level is greater than the city baseline. Once percent change from 2000-2015 
in each census tract was established, the change in each school catchment zone was be aggregated by finding the average amount of change in the census tracts that fall within a shared catchment zone. School catchment zones that demonstrate a greater change than the city of Portland in three or four of the independent variables were identified as "likely gentrifying."

Using ArcGIS these likely gentrifying school neighborhoods were identified, and all schools that are indicated as existing in gentrifying neighborhoods will be used as the experimental group which was been influenced by gentrification. While those schools that are identified as existing in neighborhoods that are not gentrifying act as a control group that are not influenced by the independent variable. School neighborhoods with dramatically shifted catchment zones, recently opened schools, or recently closed schools will be excluded from the study.

\section{Spatial Data and Maps}

Data was collected from the U.S. Census and the American Community Survey (ACS) on the census tract level. A comparison of the 2000 and 2015 census tracts (appendix A: Geographic Boundary Changes) reveals new and changed geographical boundaries amongst various tracts. In cases of tract changes data from the 2000 census was split and merged in order to create appropriate comparison groups to the 2015 census tracts. 
To identify gentrifying school neighborhoods, school catchment zones (also known as attendance areas) were used to define a school neighborhood. Using areal interpolation data from the census tract level were mapped to the catchment zones.

Census tracts and school catchment zones can be found in appendix A: Geographic Boundary Changes. A complete list of census tract and school changes and mergers can be found in the appendix B: Census and School Change Data). 


\section{Statistical Analysis}

The second part of the analysis in this paper uses data on the public school within Portland to investigate the relationship between school neighborhood change and student performance on standardized tests. Student-level data on standardized test scores obtained from the Oregon Department of Education (ODE) during the 2000-2001 school year through the 2015-2016 school year were analyzed for change over time. Longitudinal data through that period was then used to perform an analysis of the effects of gentrification on the local schools over time.

\section{Data Sources and variables}

1. PPS Enrollment Profiles

Independent Variable: Gentrifying (Yes or No?)

Dependent Variable: Percent of enrolled white students

2. Oregon Department of Education (ODE)

Independent Variable: Gentrifying (Yes or No?)

Dependent Variable A: $3^{\text {rd }}$ grade math proficiency on the Oregon assessment of knowledge and skills (OAKS)

Dependent Variable B: $3^{\text {rd }}$ grade reading proficiency on the OAKS

Because the effects of gentrification on schooling will first become evident in younger children (G. Duncan \& Murnane, 2011; Keels, Burdick-Will, \& Keene, 2013), and because parents are more involved in the younger children's daily routines (Joseph \& Feldman, 2009), this analysis relies on data from $3^{\text {rd }}$ grade standardized assessments. In addition to these reasons, in contrast to older students, the younger students are also a better indication of how the neighborhood is changing. 


\section{FINDINGS}

Fifteen school catchment zones were identified as likely gentrifying because they demonstrated uncharacteristically quick growth in median income, median home value, percent of white residents, and percent of residents over 25 years old with a bachelor's degree. Further longitudinal analysis of student performance on the standardized assessments in these schools revealed that there was no statistically significant difference between the outcome between gentrifying and non-gentrifying school neighborhoods. These findings in Portland pushes against many leading theories that gentrification results in positive academic outcomes in local public schools. While these neighborhoods might be benefiting one of the many externalities associated with gentrification, it is not clear that the gentrification of these neighborhoods has any effect on student performance of state standardized assessments.

Like findings by local scholars such as Bates (2013) and Gibson (2017), this study identified that gentrifying schools were typically found in the North-East and South-East neighborhoods of the city. In review of 2000-2015 census data 18.2 percent (26) of the 143 census tracts within Portland were identified as having a growth significantly higher than Portland in the following four criteria: Median Household income, median house value, population 25 and over with a bachelor's degree, percent of population that identifies as white. These census tracts were largely found centralized in the North East, Albina and Alberta neighborhoods. 
To measure change on a school neighborhood level, a baseline for comparison needed to be created. To create a baseline, Portland city averages on the four indicators were used as the comparison tool for determining census tract change. As seen in Table 1, it was discovered that of the four variables of interest in this study, levels of higher education grew at a much faster rate than the other three variables. While incomes stayed stagnant, the boom in the housing market can be seen across the city. We can see widespread trends in the city level data, but by breaking it down to the census level we get a more refined picture of what is happening on a neighborhood level.

Table 1. Portland Indicators of Neighborhood Change

\begin{tabular}{lccc}
\hline Indicator & $\mathbf{2 0 0 0}$ & $\mathbf{2 0 1 5}$ & $\begin{array}{c}\text { Percent Change } \\
\text { with MoE }\end{array}$ \\
\hline Median income* & 55,141 & 55,003 & $-0.3 \%(+/-) 1.5 \%$ \\
\hline Median home value* & 212,480 & 295,100 & $+39.1 \%(+/-) 1.4 \%$ \\
\hline $\begin{array}{l}\text { Percent of population that is white } \\
\begin{array}{l}\text { Percent of population with bachelor's } \\
\text { degree }\end{array}\end{array}$ & $77.1 \%$ & $77.6 \%$ & $+0.5 \%(+/-) 0.4 \%$ \\
\hline $\begin{array}{l}\text { Data Source: 2000 Census and 2015 ACS Survey. } \\
\text { *adjusted to 2015 dollars }\end{array}$ & & $45.5 \%$ & $+12.9 \%(+/-) 0.9 \%$ \\
\hline
\end{tabular}

Using aerial interpolation, census tract data was aggregated by school catchment zones to find the change across the four indicators in each school neighborhood. Once a percent change for each indicator was determined for every public-school neighborhood in Portland, a direct comparison could be made between the school neighborhood and city level. School neighborhoods were given a score based on whether their average for each 
indicator fell below the baseline margin of error, within the baseline margin of error, or above the baseline margin of error. Each neighborhood could have a score within the range of -4 to +4 based on how they compared to the city baseline.

For example, The Bridger elementary school neighborhood demonstrated the following key neighborhood changes:

1. Percent Change in Median Income: $-1.3 \%$

2. Percent change in median home value: $+49.5 \%$

3. Percent change in population that is white: $+1.9 \%$

4. Percent change in population with bachelor's degree : $+25 \%$

Because three of the four criteria are above the city average (median home value, population that is white, and population with a bachelor's degree) and 1 of the four criteria (median income) is not significantly different from the city average, Bridger Elementary school neighborhood was identified with a gentrification score of 3 . 
Figure 3: Gentrifying Neighborhoods and Landing Zones

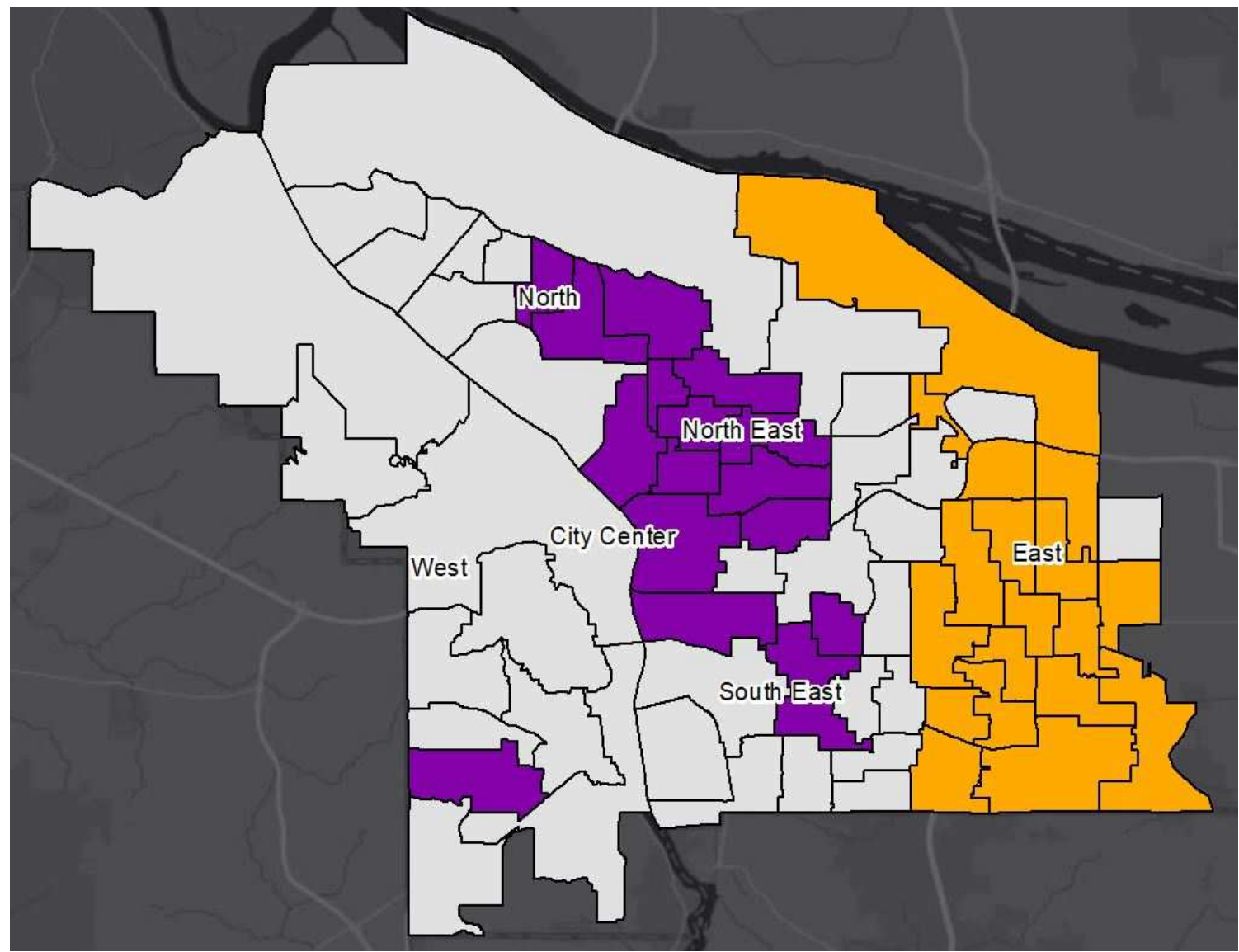

Stable Neighborhoods

Likely gentrifying

Possible landing zone

Using this method, it was determined that 17 (25\%) of the 68 public K-12 schools in Portland reside in neighborhoods that have a gentrification score of 4 indicating that they have very likely experiencing gentrification. In Figure 1. we see a tendency for gentrifying school neighborhoods to be clustered in the near-eastside regions of the city. Not surprisingly, the historically black neighborhood of Albina and nearby neighborhoods such as Alberta, which have rich histories of redlining and disinvestment, have showed strong indicators of gentrification. Further East we see neighborhoods with scores of -4, indicating 
that they are likely landing zones for those residents that have been displaced from the gentrifying communities.

This clustering of gentrifying school neighborhoods leads naturally to the question at the root of this paper; what effect if any does this concentration of neighborhood change have on the academic performance of students that attend the local public schools?

Figure 4: Stable/constant schools vs. gentrifying schools - math

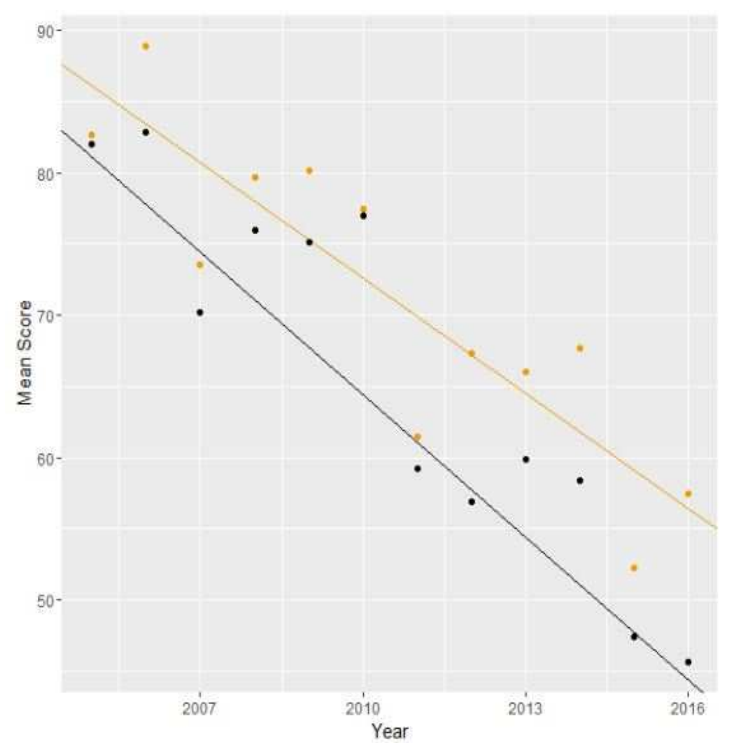

Gentrifying School Neighborhoods
Figure 5: Stable/constant schools vs. gentrifying schools - reading

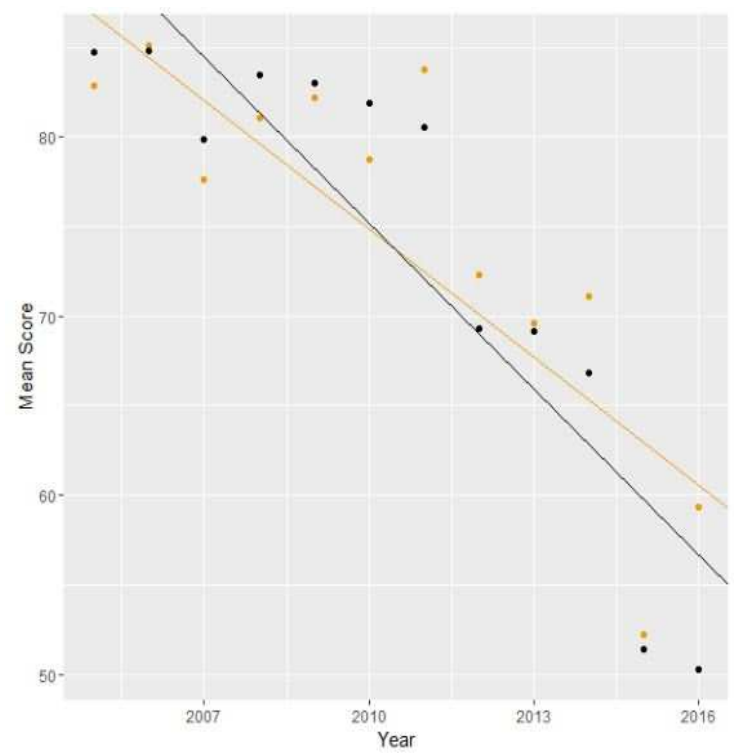

- Stable/Constant School Neighborhoods

Regression analysis of the change in test performance in gentrifying neighborhoods when compared to those that show little to no evidence of gentrification, reveals no significant difference. In Figure 3 and Figure 4, regression lines for both the constant and gentrifying 
neighborhoods shows a negative relationship between time and student performance on the math and reading state standardized tests.

Table 2: Performance on Standardized test by Neighborhood Type (2000-15)

\begin{tabular}{lllll}
\hline & \multicolumn{2}{c}{ Math } & \multicolumn{2}{c}{ Reading } \\
\hline Neighborhood Type & Slope (b) & P-value & Slope (b) & P-value \\
\hline $\begin{array}{l}\text { Stable/Constant } \\
\text { Neighborhood }\end{array}$ & -3.33 & 0.0001 & -3.09 & 0.0001 \\
\hline $\begin{array}{l}\text { Gentrifying } \\
\text { Neighborhood }\end{array}$ & -2.70 & 0.0002 & -2.39 & 0.007 \\
\hline \multicolumn{2}{l}{ Data Source: 2000 Census and 2015 ACS Survey. } & &
\end{tabular}

As seen in table 2, the negative trends of performance on the standardized test are significant findings. The trend lines show that each year results in an approximate decrease of 2.39-3.33 points on the standardized tests depending on neighborhood and content area. One can speculate as to why this trend is being experienced in Portland. Could it simply be that students are not exiting the third grade as prepared and competent as they have in previous years, or could it be more easily explained by an increased rigor in the assessments each year? The introduction of common core standard in 2014-15 suggests that increased rigor has at least something to do with the quick drop in test scores for the 2014-15 year, this outlier year fails to account for the negative trend before these years. While finding the explanation to the negative trend in data might be considered nearly impossible, an investigation into the difference between gentrifying school neighborhoods and stable or constant school neighborhoods can be quantitatively explored. 
Table 3: Change in Performance on the OAKS: Gentrifying vs. Stable Neighborhoods

\begin{tabular}{|c|c|c|c|c|c|}
\hline \multirow[b]{2}{*}{ Subject } & \multirow[b]{2}{*}{ Pair } & Paired Differences & \multirow[b]{2}{*}{ t } & \multirow[b]{2}{*}{ df } & \multirow[b]{2}{*}{$\begin{array}{r}\text { 2-tailec } \\
\text { p-val }\end{array}$} \\
\hline & & Mean & & & \\
\hline Math & $\begin{array}{l}\text { (x)Gentrifying neighborhoods- } \\
\text { (y)Stable neighborhoods }\end{array}$ & $\begin{array}{l}\text { (x) }-2.29 \\
\text { (y) }-3.30\end{array}$ & 0.288 & 20 & 0.776 \\
\hline Reading & $\begin{array}{l}\text { (x)Gentrifying neighborhoods- } \\
\text { (y)Stable neighborhoods }\end{array}$ & $\begin{array}{l}\text { (x) }-2.14 \\
\text { (y) }-3.13\end{array}$ & 0.344 & 20 & 0.734 \\
\hline
\end{tabular}

Data Source: 2000 Census and 2015 ACS Survey

In a two sample T-test (Table 2), the average performance over time of gentrifying school neighborhoods and stable neighborhoods was compared to investigate if the changing neighborhoods have had any significant effect on the state standardized math and reading test. Although the regression lines in figure 2 and figure 3 illustrate a possible trend. A Ttest analyzing the difference of means left us with P-values of 0.776 and 0.734 and a conclusion that the difference in means between gentrifying and non-gentrifying neighborhoods is not statistically significant. These results prohibit us from drawing any correlation between the performance on the OAKS standardized test and neighborhood change.

While gentrification could have a very dramatic effect on community and school dynamics, statistical analysis has failed to show any correlation between the gentrifying communities and school performance on the state standardized test. The influx of a higher educated population and higher incomes reveals a marginal and statistically insignificant difference in academic outcomes for local public schools. 


\section{CONCLUSION}

When considering the findings in this study it is important to keep in mind that this analysis only considers averages across neighborhoods. By trying to capture the larger community trends in the data, finer detailed analysis of students and schools was lost. The data gathered at this level did not allow us to explain a wider range of school outcomes and limited this study to general claims and observations.

The findings confirm that while, we might see measurable change in demographics, income, or home value in specific school neighborhoods, the change we see in academic performance on the OAKS is negligible. Expected benefits associated with gentrification fail to materialize in the test scores of local schools. While changing neighborhoods do undoubtedly have drastic effects on the schools within them, we cannot definitively say the performance of the students within these schools are changed in any statistically relevant way.

With the introduction of common core standards, the growing popularity of charter schools, and the continued presence of private schools in Portland it is hard to definitively say gentrification is having no effect on our education system. While the effects may not be witnessed in our public schools, this anomaly could be hidden by funneling of high performing students to nearby charter and private schools. Meaning the effects might be 
felt in gentrifying neighborhoods, but they are simply not spilling over into our public schools.

The growth of middle- and upper-income households and families in gentrifying neighborhoods is not connected to any meaningful change in student outcomes. It is only through neighborhood effects and the associated externalities, that come with increased economic capital in a community, that low-income children attending public schools in gentrifying neighborhoods will see any benefits. In this analysis it appears that the variables associated with gentrification and neighborhood change are not the panacea for our struggling public-school system. 


\section{REFERENCES}

Anas, A., Arnott, R., \& Small, K. A. (1998). Spatial Structure. Journal of Economic Literature, 36(3), 1426-1464.

Balfanz, R., Herzog, L., \& Mac Iver, D. J. (2007). Preventing Student Disengagement and Keeping Students on the Graduation Path in Urban Middle-Grades Schools: Early Identification and Effective Interventions. Educational Psychologist, 42(4), 223-235. https://doi.org/10.1080/00461520701621079

Bates, L. K. (2013). Gentrification and Displacement Study: Implementing an Equitable Inclusive Development Startegy in the Context of Gentrification. PDXScholar. Portland.

Byrne, J. P. (2003). Two Cheers for Gentrification. Howard Law Journal, 46(3), 405432. Retrieved from http://scholarship.law.georgetown.edu/facpub/930

Catterall, J. S. (1987). On the Social Costs of Dropping out of School. The Highschool Journal, 71(1), 19-30.

Chen, G. (2008). Communities, students, and school crime: A confirmatory Study of Crime in U.S. High Schools. Urban Education, 43(3), 301-318.

Coleman, J. S. (1988). Social Capital in the Creation of Human Capital. American Journal of Sociology, 94, S95.

Coleman, J. S., Campbell, E. Q., Hobson, C. J., McPartland, J., Mood, A. M., Weinfeld, F. D., \& York, R. L. (1966). Equality of Educational Opportunity. Washington, DC.

Davidson, M., \& Martin, D. (2014). Urban Politics: Critical Approaches. (M. Davidson \& D. Martin, Eds.).

Davis-Kean, P. E. (2005). The Influence of Parent Education and Family Income on Child Achievement: The Indirect Role of Parental Expectations and the Home Environment. Journal of Family Psychology, 19(2), 294-304. https://doi.org/10.1037/0893-3200.19.2.294

Davis, T., \& Oakley, D. (2013). Linking charter school emergence to urban revitalization and gentrification: A socio-spatial analysis of three cities. Journal of Urban Affairs. https://doi.org/10.1111/juaf.12002

Dee, T. S., \& Jacob, B. A. (2010). The Impact of No Child Left Behind on Students, Teachers, and Schools. Brookings Papers on Economic Activity, 1-52.

Defilippis, J., \& Fraser, J. C. (2010). Why Do We Want Mixed- Income Housing and Neighborhoods. Critical Urban Studies: New Directions, 135-146.

Desena, J. N. (2006). “What's a Mother To Do?" Gentrification, School Selection, and the Consequences for Community Cohesion. American Behavioral Scientist, 50(2), 241-257. https://doi.org/10.1177/0002764206290639

Desena, J. N., \& Ansalone, G. (2009). Gentrification, Schooling and Social Inequality. Educational Research Quarterly, 33(1), 60-74.

Duncan, G. J., \& Murnane, R. J. (2014). Growing Income Inequality Threatens American Education. Phi Delta Kappa International, 95(6), 8-14.

Duncan, G., \& Murnane, R. (2011). Introduction: The American Dream Then and Now. In G. Duncan \& R. Murnane (Eds.), Whither Opportunity (pp. 3-23). 
EOGOAC. (2015). Closing the Opportunity Gap.

Farkas, G. (2008). How Educational Inequality Develops. In C. Lin \& D. Harris (Eds.), The Colors of Poverty: Why Racial and Ethnic Disparities Persist. New York: Russel Sage Foundation.

Freeman, L., \& Braconi, F. (2004). Gentrification and Displacement New York City in the 1990s. Journal of the American Planning Association, 70(1), 39-52. https://doi.org/10.1080/01944360408976337

Garcia, D. R. (2008). Academic and Racial Segregation in Charter Schools Do Parents Sort Students Into Specialized Charter Schools? Education and Urban Society, 40(5), 590-612. https://doi.org/10.1177/0013124508316044

Gardner, H. (1992). Assessment in Context: The Alternatives to Standardized Testing. https://doi.org/10.1007/978-94-011-2968-8

Gibson, K. J. (2007). Bleeding Albina: A History of Community Disinvestment, 19402000. Transforming Anthropology, 15(1), 3-25.

Gregory, A., Skiba, R. J., \& Noguera, P. A. (2010). The Achievement Gap and the Discipline Gap: Two Sides of the Same Coin? Educational Researcher, 39(1), 5968. https://doi.org/10.3102/0013189X09357621

Harding, A., \& Blokland, T. (2014). Urban Theory: A Critical Introduction to Power, Cities, and Urbanism in the 21st Century.

Jordan, R., \& Gallagher, M. (2014). Does School Choice Affect Gentrification? Posing the Question and Assessing the Evidence. Washington, DC.

Joseph, M., \& Feldman, J. (2009). Creating and Sustaining Successful Mixed-Income Communities: Conceptualizing the Role of Schools. Education and Urban Society, 41(6), 623-652. https://doi.org/10.1177/0013124508329833

Keels, M., Burdick-Will, J., \& Keene, S. (2013). The Effects of Gentrification on Neighborhood Public Schools. City and Community, 12(3), 238-259. https://doi.org/10.1111/cico.12027

Lees, L. (2008). Gentrification and Social Mixing: Towards an Inclusive Urban Renaissance? Urban Studies, 45(12), 2449-2470. https://doi.org/10.1177/0042098008097099

Ley, D. (1986). Alternative Explanations for Inner-City Gentrification : A Canadian Assessment. Annals of the Association of American Geographers, 76(4), 521-535.

Lipman, P. (2004). High Stakes Education: Inequality, Globalization, and Urban School Reform. New York: Routledge Falmer.

Lipman, P. (2008). Mixed-Income Schools and Housing: Advancing the Neoliberal Urban Agenda. Journal of Education Policy, 23(2), 119-134.

Lipsitz, G. (1994). The Racialization of Space and the Spatiaiization of Race. Landscape Journal, 26(1), 10-23.

McKinnish, T., Walsh, R., \& Kirk White, T. (2010). Who gentrifies low-income neighborhoods? Journal of Urban Economics, 67(2), 180-193. https://doi.org/10.1016/j.jue.2009.08.003

Owen, W. (2011, July 22). New Oregon law will make it easier for students to transfer between districts, beginning in $2012 \square 13$ school year. The Oregonian, p. 3. 
Portland.

Patrick Heidkamp, C., \& Lucas, S. (2006). Finding the Gentrification Frontier Using Census Data: The Case of Portland. Urban Geography, 27(2), 101-125.

Reardon, S. F. (2011). The Widening Academic Achievement Gap Between the Rich and the Poor: New Evidence and Possible Explanations. In Whither Opportunity? Rising Inequality and the Uncertain Life Chances of Low-Income Children (pp. 91-116). https://doi.org/10.3102/00028312042002305

Redfern, P. A. (2003). What Makes Gentrification “Gentrification”? Urban Studies, 40(12), 2351-2366. https://doi.org/10.1080/0042098032000136101

Rumberger, R. W. (2001). Why Students Drop Out of School and What Can be Done. The Civil Right Project, 153.

Sandy, J., Duncan, K., \& Cede, F. (2010). Examining the achievement test score gap between urban and suburban students. Education Economics, 18(3), 297-315. https://doi.org/10.1080/09645290903465713

Serbulo, L., \& Gibson, K. J. (2013). Black and Blue: Police-community relations in Portland's Albina District, 1964-1985. Oregon Historical Society, 114(1), 6-37.

Silverman, R. M. (2014). Urban, Suburban, and Rural Contexts of School Districts and Neighborhood Revitalization Strategies: Rediscovering Equity in Education Policy and Urban Planning. Leadership and Policy in Schools, 13, 3-27. https://doi.org/10.1080/15700763.2013.876051

Slater, T. (2006). The Eviction of Critical Perspectives from Gentrification Research. International Journal of Urban and Regional Research, 30(4), 737-57. https://doi.org/10.1111/j.1468-2427.2006.00689.x

Slater, T. (2013). Gentrification of the City. In G. Bridge \& S. Watson (Eds.), The New Blackwell Companion to the City. John Wiley \& Sons.

Smith, A., \& Timar, J. (2010). Uneven transformations: Space, economy and society 20 years after the collapse of state socialism. European Urban and Regional Studies, 17(2), 115-125. https://doi.org/10.1177/0969776409358245

Smith, N. (1979). Toward a Theory of Gentrification A Back to the City Movement by Capital, not People. Journal of the American Planning Association, 45(4), 538-548. https://doi.org/10.1080/01944367908977002

Smith, N. (1987). Gentrification and the Rent Gap. Annals of the Association of American Geographers, 77(3), 462-465.

Sullivan, D. M. (2007). Reassessing Gentrification Measuring Residents' Opinions Using Survey Data. Urban Affairs Review, 42(4), 583-592. https://doi.org/10.1177/1078087406295828

Vargyas, E. J., \& Connor, K. (2013). The Legal Implications of Gender Bias in Standardized Testing The Legal Implications of Gender Bias in Standardized Testing. Berkely Journal of Gender, Law \& Justice, 7(1).

Vigdor, J. L. (2002). Does Gentrification Harm the Poor? Brookings-Wharton Papers on Urban Affairs, 182(2002), 133-182. https://doi.org/10.1353/urb.2002.0012

Wacquant, L. (2007). Territorial Stigmatization in the Age of Advanced Marginality. Thesis Eleven, 91(1), 66-77. https://doi.org/10.1177/0725513607082003 
Warren, M. R. (2005). Communities and Schools: A New View of Urban Education Reform. Harvard Educational Review, 75(2), 133-173.

Wharton, J. L. (2008). Gentrification: The New Colonialism in the Modern Era. The Forum on Public Policy, 10-13.

Wyly, E. K., \& Hammel, D. J. (1998). Modeling the Context and Contingency of Gentrification. Journal of Urban Affairs, 20(3), 303-326.

Zuk, M., Bierbaum, A. H., Chapple, K., Gorska, K., Loukaitou-sideris, A., Ong, P., \& Thomas, T. (2015). Gentrification, Displacement and the Role of Public Investment: A Literature Review. University of Berkeley, 76. 


\section{APPENDIX A: Geographic Boundary Changes}

\section{Figure 1A: 2000 Census Tracts}

Pictured below is the geography of the census tracts during 2000, for more detail on how the census tracts changed over the course of the study please refer to Table 1B in Appendix B: Tables

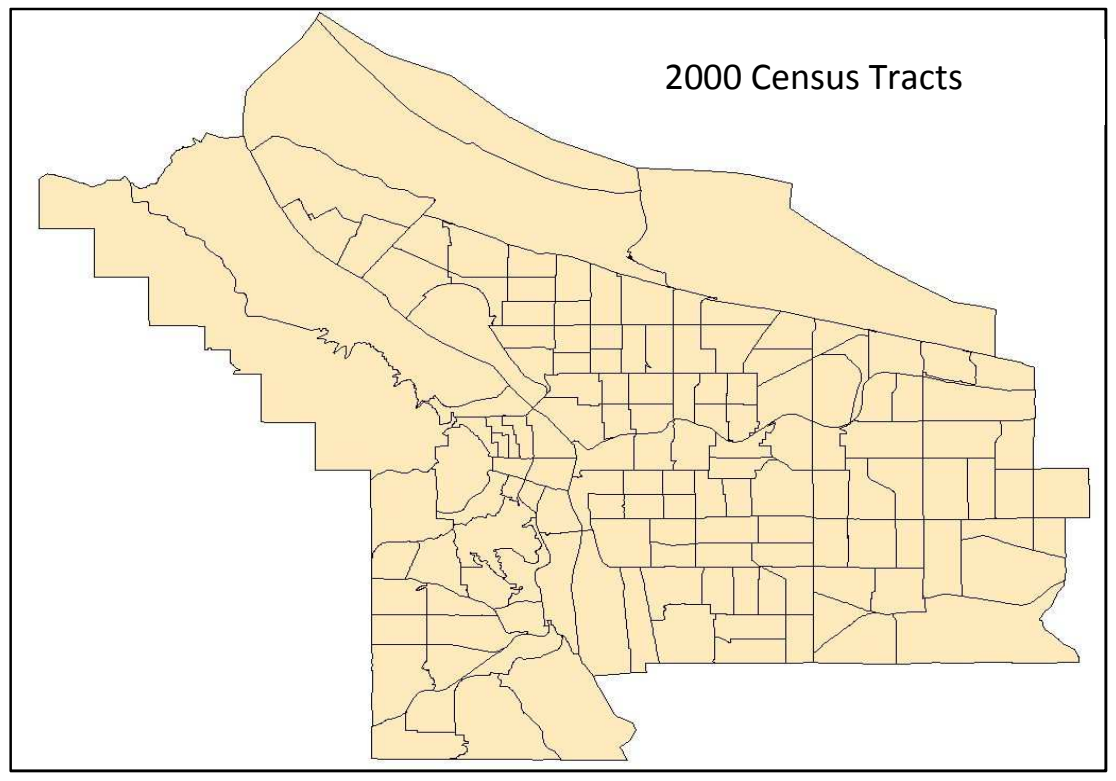

Figure 2A: 2015 Census Tracts

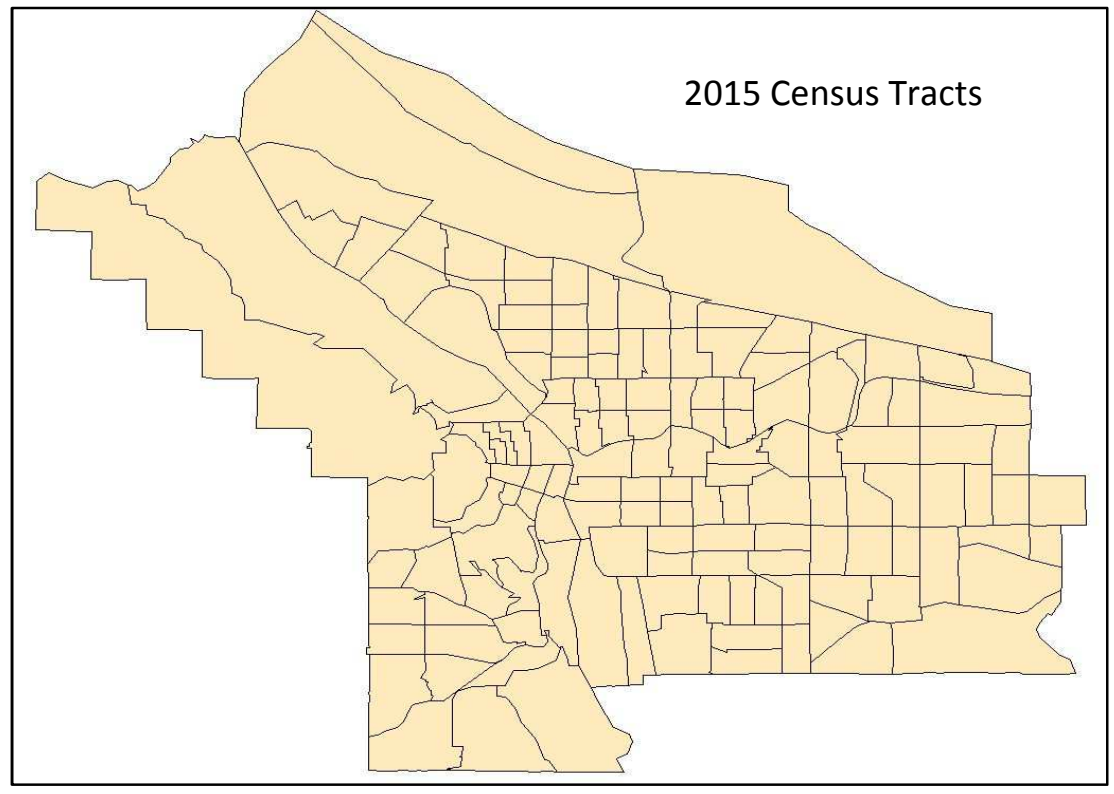


Figure \#A: School Catchment Zone

Because census tracts do not map neatly over school catchment zones, a method of aerial interpolation was used to aggregate census tract data to the school boundary areas throughout the study area.

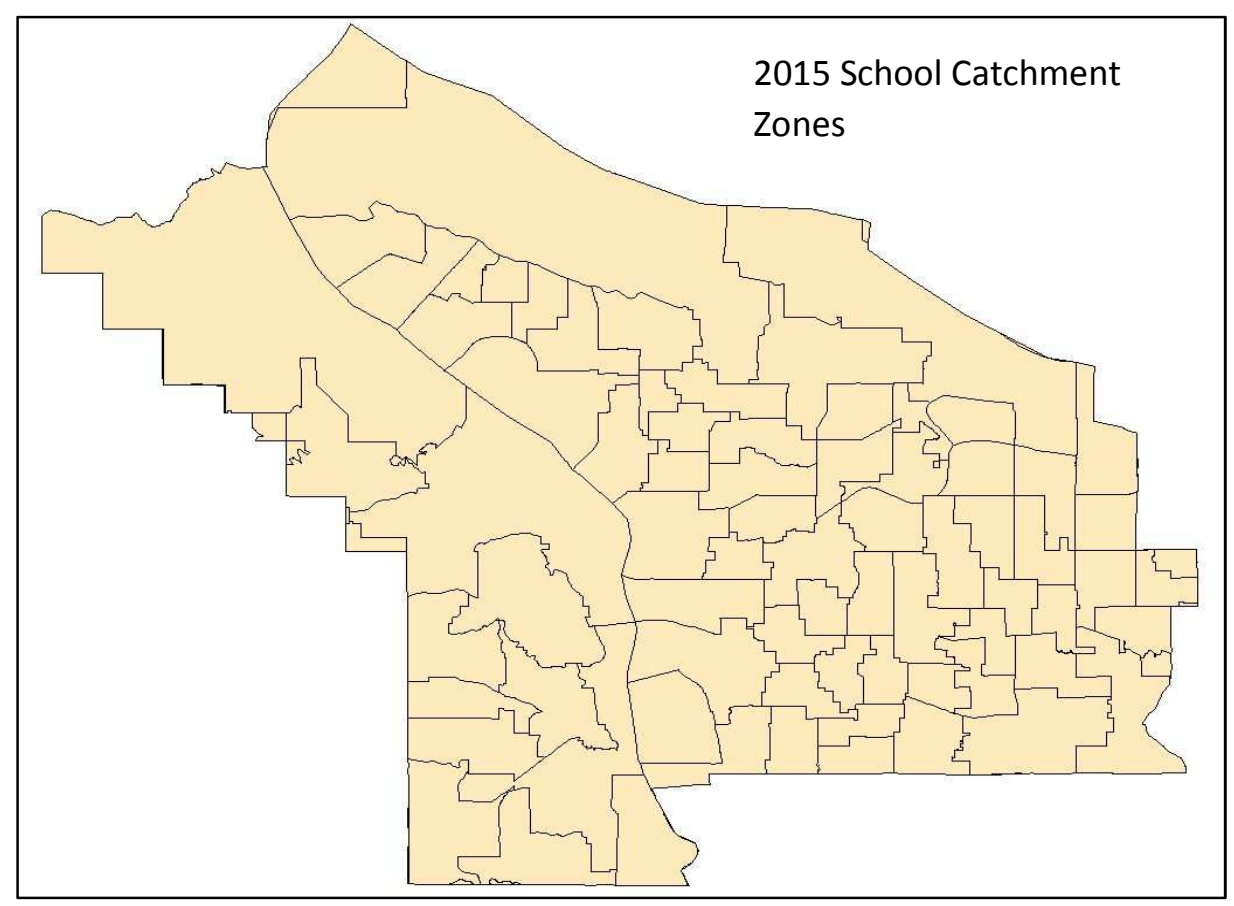




\section{APPENDIX B: Census and School Change Data}

\section{Table 1B: Census Tract Changes and Mergers}

Due to the change in geography of certain census tracks throughout the study area, several census tracts in the 2000 data set had to be merged or split in order for a direct comparison to 2015 census tract data.

\begin{tabular}{lll}
$\mathbf{2 0 0 0}$ Tracts & Action & 2015 Tracts \\
\hline 44 & renamed & 9800 \\
\hline $22.01 \& 23.01$ & merged & 22.03 \\
\hline $22.01 \& 23.02$ & merged & 23.02 \\
\hline $53 \& 54$ & merged & 106 \\
\hline 64.01 & split & $64.03 \& 64.04$ \\
\hline
\end{tabular}

\section{Table 2B: School Name Change and Mergers}

Over the 2000-2015 school years there were several changes made to the schools in the study area. The table below details the year a change occurred, the name of the school and the action that was taken.

\begin{tabular}{lll} 
Year & School & Action \\
\hline 2005 & Ball Elm & $\begin{array}{l}\text { Was closed (removed from } \\
\text { analysis) }\end{array}$ \\
\hline 2007 & Clarendon-Portmouth & Reopened as César Chávez \\
\hline 2007 & Clark & Reopened as Harrison Park \\
\hline 2007 & Hoolyrood \& Fernwood & Merged into Beverly Cleary \\
\hline 2007 & Humboldt & Merged with Boise-Eliot \\
\hline 2007 & Rose City & Reopened as Roseway heights \\
\hline
\end{tabular}

\section{Table 3B: Portland 2000-2015 Indicators of Change}

Below are the key variables of neighborhood change used in this study. These values were used to create a baseline for neighborhood comparison.

\begin{tabular}{lrrr}
\hline Indicator & $\mathbf{2 0 0 0}$ & $\mathbf{2 0 1 5}$ & \multicolumn{1}{c}{$\begin{array}{c}\text { Percent Change } \\
\text { with MoE }\end{array}$} \\
\hline Median income* & 55,141 & 55,003 & $-0.3 \%(+/-) 1.5 \%$ \\
\hline Median home value* & 212,480 & 295,100 & $+39.1 \%(+/-) 1.4 \%$ \\
\hline Percent of population that is white & $77.1 \%$ & $77.6 \%$ & $+0.5 \%(+/-) 0.4 \%$ \\
\hline $\begin{array}{l}\text { Percent of population with } \\
\text { bachelor's degree }\end{array}$ & $32.6 \%$ & $45.5 \%$ & $+12.9 \%(+/-) 0.9 \%$ \\
\hline Data & &
\end{tabular}

Data collected from the 2000 Census and 2015 ACS survey

*Median Income and Median home values adjusted to 2015 dollars 
Table 4B: Indicators of Neighborhood Change by School Neighborhood

\begin{tabular}{|c|c|c|c|c|c|c|}
\hline School Name & $\begin{array}{l}\text { \%Change } \\
\text { in } \\
\text { Population }\end{array}$ & $\begin{array}{l}\text { \%Change } \\
\text { in } \\
\text { Population } \\
\text { of White } \\
\text { Residents }\end{array}$ & $\begin{array}{l}\text { \%Change } \\
\text { in } \\
\text { Median } \\
\text { Income }\end{array}$ & $\begin{array}{l}\text { \%Change } \\
\text { in Median } \\
\text { Home } \\
\text { Value } \\
\end{array}$ & $\begin{array}{l}\text { \%Change } \\
\text { in } \\
\text { Population } \\
\text { with } \\
\text { Bachelor's } \\
\text { degree } \\
\end{array}$ & $\begin{array}{l}\text { Gentrification } \\
\text { Score }\end{array}$ \\
\hline $\begin{array}{l}\text { Abernethy } \\
\text { Elementary }\end{array}$ & $20.7 \%$ & $1.2 \%$ & $10.0 \%$ & $56.6 \%$ & $32.0 \%$ & 4 \\
\hline $\begin{array}{l}\text { Ainsworth } \\
\text { Elementary }\end{array}$ & $14.9 \%$ & $-7.0 \%$ & $8.0 \%$ & $16.5 \%$ & $39.7 \%$ & 0 \\
\hline $\begin{array}{l}\text { Alameda } \\
\text { Elementary }\end{array}$ & $8.5 \%$ & $2.4 \%$ & $15.5 \%$ & $59.4 \%$ & $35.8 \%$ & 4 \\
\hline $\begin{array}{l}\text { Arleta } \\
\text { Elementary }\end{array}$ & $-0.5 \%$ & $0.2 \%$ & $-2.1 \%$ & $37.6 \%$ & $26.8 \%$ & -1 \\
\hline $\begin{array}{l}\text { Astor } \\
\text { Elementary }\end{array}$ & $24.5 \%$ & $-1.4 \%$ & $-0.7 \%$ & $58.4 \%$ & $21.4 \%$ & 1 \\
\hline $\begin{array}{l}\text { Atkinson } \\
\text { Elementary }\end{array}$ & $0.9 \%$ & $3.0 \%$ & $3.3 \%$ & $54.0 \%$ & $29.5 \%$ & 4 \\
\hline $\begin{array}{l}\text { Beach } \\
\text { Elementary }\end{array}$ & $7.0 \%$ & $13.5 \%$ & $-65.2 \%$ & $-37.7 \%$ & $32.9 \%$ & 0 \\
\hline $\begin{array}{l}\text { Beverly } \\
\text { Cleary }\end{array}$ & $11.2 \%$ & $2.2 \%$ & $8.0 \%$ & $56.0 \%$ & $35.5 \%$ & 4 \\
\hline $\begin{array}{l}\text { Boise-Eliot } \\
\text { Elementary }\end{array}$ & $32.3 \%$ & $26.4 \%$ & $27.8 \%$ & $68.3 \%$ & $35.0 \%$ & 4 \\
\hline $\begin{array}{l}\text { Bridger } \\
\text { Elementary }\end{array}$ & $0.7 \%$ & $1.9 \%$ & $-1.3 \%$ & $49.5 \%$ & $25.0 \%$ & 3 \\
\hline $\begin{array}{l}\text { Bridlemile } \\
\text { Elementary }\end{array}$ & $11.5 \%$ & $-2.7 \%$ & $9.6 \%$ & $31.4 \%$ & $37.7 \%$ & 0 \\
\hline $\begin{array}{l}\text { Buckman } \\
\text { Elementary }\end{array}$ & $6.8 \%$ & $3.5 \%$ & $8.2 \%$ & $52.5 \%$ & $29.6 \%$ & 4 \\
\hline $\begin{array}{l}\text { Capitol Hill } \\
\text { Elementary }\end{array}$ & $33.4 \%$ & $-2.4 \%$ & $-2.7 \%$ & $30.9 \%$ & $33.4 \%$ & -2 \\
\hline $\begin{array}{l}\text { César Chávez } \\
\text { K-8 }\end{array}$ & $36.9 \%$ & $4.5 \%$ & $-12.1 \%$ & $32.0 \%$ & $13.3 \%$ & -1 \\
\hline $\begin{array}{l}\text { Chapman } \\
\text { Elementary }\end{array}$ & $37.3 \%$ & $-2.1 \%$ & $4.7 \%$ & $17.6 \%$ & $34.6 \%$ & 0 \\
\hline $\begin{array}{l}\text { Cherry Park } \\
\text { Elementary }\end{array}$ & $21.4 \%$ & $-11.8 \%$ & $-32.6 \%$ & $8.0 \%$ & $11.0 \%$ & -4 \\
\hline $\begin{array}{l}\text { Chief Joseph } \\
\text { Elementary }\end{array}$ & $11.9 \%$ & $9.0 \%$ & $5.5 \%$ & $60.7 \%$ & $31.7 \%$ & 4 \\
\hline $\begin{array}{l}\text { Creston } \\
\text { Elementary }\end{array}$ & $-0.3 \%$ & $5.2 \%$ & $6.2 \%$ & $41.2 \%$ & $30.5 \%$ & 4 \\
\hline $\begin{array}{l}\text { Duniway } \\
\text { Elementary }\end{array}$ & $7.6 \%$ & $-0.6 \%$ & $17.1 \%$ & $45.3 \%$ & $36.5 \%$ & 2 \\
\hline $\begin{array}{l}\text { Earl Boyles } \\
\text { Elementary }\end{array}$ & $17.5 \%$ & $-9.1 \%$ & $-24.7 \%$ & $5.9 \%$ & $8.4 \%$ & -4 \\
\hline $\begin{array}{l}\text { Faubion } \\
\text { Elementary }\end{array}$ & $9.9 \%$ & $4.9 \%$ & $-14.1 \%$ & $25.3 \%$ & $19.9 \%$ & 0 \\
\hline
\end{tabular}




\begin{tabular}{|c|c|c|c|c|c|c|}
\hline School Name & $\begin{array}{l}\text { \%Change } \\
\text { in } \\
\text { Population }\end{array}$ & $\begin{array}{l}\% \text { Change } \\
\text { in } \\
\text { Population } \\
\text { of White } \\
\text { Residents }\end{array}$ & $\begin{array}{l}\text { \%Change } \\
\text { in } \\
\text { Median } \\
\text { Income }\end{array}$ & $\begin{array}{l}\text { \%Change } \\
\text { in Median } \\
\text { Home } \\
\text { Value }\end{array}$ & $\begin{array}{l}\% \text { Change } \\
\text { in } \\
\text { Population } \\
\text { with } \\
\text { Bachelor's } \\
\text { degree }\end{array}$ & $\begin{array}{l}\text { Gentrification } \\
\text { Score }\end{array}$ \\
\hline $\begin{array}{l}\text { Forest Park } \\
\text { Elementary }\end{array}$ & $66.3 \%$ & $-11.3 \%$ & $-8.3 \%$ & $10.1 \%$ & $34.2 \%$ & -2 \\
\hline $\begin{array}{l}\text { Gilbert } \\
\text { Heights } \\
\text { Elementary }\end{array}$ & $38.7 \%$ & $-12.5 \%$ & $-23.4 \%$ & $-1.6 \%$ & $9.3 \%$ & -4 \\
\hline $\begin{array}{l}\text { Gilbert Park } \\
\text { Elementary }\end{array}$ & $50.0 \%$ & $-14.2 \%$ & $-12.5 \%$ & $4.7 \%$ & $10.8 \%$ & -4 \\
\hline $\begin{array}{l}\text { Glencoe } \\
\text { Elementary }\end{array}$ & $10.2 \%$ & $0.1 \%$ & $3.0 \%$ & $51.9 \%$ & $28.0 \%$ & 2 \\
\hline $\begin{array}{l}\text { Glenfair } \\
\text { Elementary }\end{array}$ & $36.9 \%$ & $-6.5 \%$ & $1.0 \%$ & $0.6 \%$ & $7.0 \%$ & -3 \\
\hline $\begin{array}{l}\text { Grout } \\
\text { Elementary }\end{array}$ & $11.1 \%$ & $1.9 \%$ & $-2.5 \%$ & $53.6 \%$ & $23.4 \%$ & 2 \\
\hline Harrison Park & $33.7 \%$ & $-20.0 \%$ & $-24.5 \%$ & $18.3 \%$ & $9.9 \%$ & -4 \\
\hline $\begin{array}{l}\text { Hayhurst } \\
\text { Elementary }\end{array}$ & $12.9 \%$ & $-4.3 \%$ & $0.7 \%$ & $35.2 \%$ & $26.6 \%$ & -1 \\
\hline $\begin{array}{l}\text { Irvington } \\
\text { Elementary }\end{array}$ & $-0.2 \%$ & $11.7 \%$ & $15.2 \%$ & $58.9 \%$ & $35.1 \%$ & 4 \\
\hline $\begin{array}{l}\text { James John } \\
\text { Elementary }\end{array}$ & $12.5 \%$ & $4.7 \%$ & $0.1 \%$ & $37.4 \%$ & $25.4 \%$ & 1 \\
\hline $\begin{array}{l}\text { Kelly } \\
\text { Elementary }\end{array}$ & $17.3 \%$ & $-4.6 \%$ & $-10.9 \%$ & $3.5 \%$ & $9.3 \%$ & -4 \\
\hline $\begin{array}{l}\text { King } \\
\text { Elementary }\end{array}$ & $6.1 \%$ & $35.6 \%$ & $56.6 \%$ & $91.9 \%$ & $41.1 \%$ & 4 \\
\hline $\begin{array}{l}\text { Laurelhurst } \\
\text { Elementary }\end{array}$ & $8.4 \%$ & $1.0 \%$ & $4.9 \%$ & $62.4 \%$ & $35.0 \%$ & 4 \\
\hline $\begin{array}{l}\text { Lee } \\
\text { Elementary }\end{array}$ & $12.3 \%$ & $-5.0 \%$ & $-17.2 \%$ & $22.1 \%$ & $22.2 \%$ & -2 \\
\hline $\begin{array}{l}\text { Lent } \\
\text { Elementary }\end{array}$ & $15.9 \%$ & $-1.1 \%$ & $-11.4 \%$ & $7.9 \%$ & $11.7 \%$ & -4 \\
\hline $\begin{array}{l}\text { Lewis } \\
\text { Elementary }\end{array}$ & $12.8 \%$ & $-0.1 \%$ & $13.5 \%$ & $32.4 \%$ & $28.0 \%$ & 0 \\
\hline $\begin{array}{l}\text { Lincoln Park } \\
\text { Elementary } \\
\end{array}$ & $27.3 \%$ & $-13.1 \%$ & $-25.9 \%$ & $-6.6 \%$ & $6.0 \%$ & -4 \\
\hline $\begin{array}{l}\text { Llewellyn } \\
\text { Elementary }\end{array}$ & $13.5 \%$ & $-1.1 \%$ & $7.8 \%$ & $56.4 \%$ & $27.0 \%$ & 2 \\
\hline $\begin{array}{l}\text { Maplewood } \\
\text { Elementary }\end{array}$ & $16.3 \%$ & $3.4 \%$ & $7.8 \%$ & $42.3 \%$ & $30.3 \%$ & 4 \\
\hline $\begin{array}{l}\text { Markham } \\
\text { Elementary } \\
\text { School }\end{array}$ & $12.2 \%$ & $-3.3 \%$ & $-3.2 \%$ & $26.0 \%$ & $21.0 \%$ & -2 \\
\hline $\begin{array}{l}\text { Marysville } \\
\text { Elementary }\end{array}$ & $7.7 \%$ & $-1.1 \%$ & $-6.6 \%$ & $27.4 \%$ & $18.6 \%$ & -2 \\
\hline
\end{tabular}




\begin{tabular}{|c|c|c|c|c|c|c|}
\hline School Name & $\begin{array}{l}\text { \%Change } \\
\text { in } \\
\text { Population }\end{array}$ & $\begin{array}{l}\text { \%Change } \\
\text { in } \\
\text { Population } \\
\text { of White } \\
\text { Residents } \\
\end{array}$ & $\begin{array}{l}\text { \%Change } \\
\text { in } \\
\text { Median } \\
\text { Income }\end{array}$ & $\begin{array}{l}\text { \%Change } \\
\text { in Median } \\
\text { Home } \\
\text { Value } \\
\end{array}$ & $\begin{array}{l}\text { \%Change } \\
\text { in } \\
\text { Population } \\
\text { with } \\
\text { Bachelor's } \\
\text { degree }\end{array}$ & $\begin{array}{l}\text { Gentrification } \\
\text { Score }\end{array}$ \\
\hline $\begin{array}{l}\text { Menlo Park } \\
\text { Elementary }\end{array}$ & $19.3 \%$ & $-9.8 \%$ & $-21.6 \%$ & $-6.1 \%$ & $6.0 \%$ & -4 \\
\hline $\begin{array}{l}\text { Mill Park } \\
\text { Elementary }\end{array}$ & $43.1 \%$ & $-14.3 \%$ & $-24.2 \%$ & $2.8 \%$ & $8.3 \%$ & -4 \\
\hline $\begin{array}{l}\text { Parklane } \\
\text { Elementary }\end{array}$ & $16.8 \%$ & $-10.1 \%$ & $-25.2 \%$ & $-4.5 \%$ & $5.7 \%$ & -4 \\
\hline $\begin{array}{l}\text { Peninsula } \\
\text { Elementary }\end{array}$ & $12.7 \%$ & $8.8 \%$ & $3.3 \%$ & $42.4 \%$ & $21.9 \%$ & 4 \\
\hline $\begin{array}{l}\text { Pleasant } \\
\text { Valley } \\
\text { Elementary }\end{array}$ & $41.3 \%$ & $-10.6 \%$ & $-16.1 \%$ & $2.7 \%$ & $8.4 \%$ & -4 \\
\hline $\begin{array}{l}\text { Prescott } \\
\text { Elementary }\end{array}$ & $5.6 \%$ & $-9.5 \%$ & $-15.5 \%$ & $6.0 \%$ & $15.4 \%$ & -2 \\
\hline $\begin{array}{l}\text { Rieke } \\
\text { Elementary }\end{array}$ & $9.8 \%$ & $-2.0 \%$ & $7.8 \%$ & $30.7 \%$ & $33.4 \%$ & 0 \\
\hline $\begin{array}{l}\text { Rigler } \\
\text { Elementary }\end{array}$ & $12.0 \%$ & $3.2 \%$ & $-24.5 \%$ & $27.5 \%$ & $20.3 \%$ & 0 \\
\hline $\begin{array}{l}\text { Rosa Parks } \\
\text { Elementary }\end{array}$ & $21.2 \%$ & $7.8 \%$ & $1.2 \%$ & $38.6 \%$ & $17.6 \%$ & 2 \\
\hline $\begin{array}{l}\text { Roseway } \\
\text { Heights }\end{array}$ & $-4.3 \%$ & $7.0 \%$ & $-2.4 \%$ & $49.6 \%$ & $26.6 \%$ & 2 \\
\hline $\begin{array}{l}\text { Russell } \\
\text { Academy }\end{array}$ & $12.9 \%$ & $-9.3 \%$ & $-17.9 \%$ & $5.6 \%$ & $11.1 \%$ & -4 \\
\hline $\begin{array}{l}\text { Sabin } \\
\text { Elementary }\end{array}$ & $8.4 \%$ & $21.2 \%$ & $30.9 \%$ & $80.5 \%$ & $35.6 \%$ & 4 \\
\hline $\begin{array}{l}\text { Sacramento } \\
\text { Elementary }\end{array}$ & $4.7 \%$ & $-4.5 \%$ & $-6.2 \%$ & $5.1 \%$ & $9.3 \%$ & -4 \\
\hline $\begin{array}{l}\text { Scott } \\
\text { Elementary }\end{array}$ & $-1.2 \%$ & $6.0 \%$ & $-1.9 \%$ & $38.9 \%$ & $20.1 \%$ & 1 \\
\hline Shaver School & $1.6 \%$ & $-5.8 \%$ & $-29.0 \%$ & $8.0 \%$ & $9.8 \%$ & -4 \\
\hline $\begin{array}{l}\text { Sitton } \\
\text { Elementary }\end{array}$ & $3.5 \%$ & $11.4 \%$ & $6.4 \%$ & $32.1 \%$ & $26.5 \%$ & 2 \\
\hline $\begin{array}{l}\text { Skyline } \\
\text { Elementary }\end{array}$ & $51.6 \%$ & $-10.0 \%$ & $4.0 \%$ & $13.0 \%$ & $32.4 \%$ & 0 \\
\hline $\begin{array}{l}\text { Sunnyside } \\
\text { Environmenta } \\
1\end{array}$ & $10.8 \%$ & $0.0 \%$ & $11.4 \%$ & $52.4 \%$ & $31.4 \%$ & 2 \\
\hline $\begin{array}{l}\text { Ventura Park } \\
\text { Elementary }\end{array}$ & $29.4 \%$ & $-16.1 \%$ & $-21.6 \%$ & $6.4 \%$ & $10.1 \%$ & -4 \\
\hline $\begin{array}{l}\text { Vernon } \\
\text { Elementary }\end{array}$ & $6.1 \%$ & $15.0 \%$ & $20.2 \%$ & $66.9 \%$ & $34.2 \%$ & 4 \\
\hline $\begin{array}{l}\text { Vestal } \\
\text { Elementary }\end{array}$ & $4.6 \%$ & $-2.3 \%$ & $8.3 \%$ & $35.6 \%$ & $25.9 \%$ & 0 \\
\hline
\end{tabular}




\begin{tabular}{|c|c|c|c|c|c|c|}
\hline School Name & $\begin{array}{l}\text { \%Change } \\
\text { in } \\
\text { Population }\end{array}$ & $\begin{array}{l}\text { \%Change } \\
\text { in } \\
\text { Population } \\
\text { of White } \\
\text { Residents }\end{array}$ & $\begin{array}{l}\text { \%Change } \\
\text { in } \\
\text { Median } \\
\text { Income }\end{array}$ & $\begin{array}{l}\text { \%Change } \\
\text { in Median } \\
\text { Home } \\
\text { Value }\end{array}$ & $\begin{array}{l}\text { \%Change } \\
\text { in } \\
\text { Population } \\
\text { with } \\
\text { Bachelor's } \\
\text { degree }\end{array}$ & $\begin{array}{l}\text { Gentrification } \\
\text { Score }\end{array}$ \\
\hline $\begin{array}{l}\text { West } \\
\text { Powellhurst } \\
\text { Elementary }\end{array}$ & $31.0 \%$ & $-10.5 \%$ & $-31.2 \%$ & $-1.3 \%$ & $1.6 \%$ & -4 \\
\hline $\begin{array}{l}\text { Whitman } \\
\text { Elementary }\end{array}$ & $24.5 \%$ & $6.1 \%$ & $1.0 \%$ & $17.4 \%$ & $11.9 \%$ & -1 \\
\hline $\begin{array}{l}\text { Woodlawn } \\
\text { Elementary }\end{array}$ & $5.7 \%$ & $21.4 \%$ & $5.5 \%$ & $54.0 \%$ & $34.3 \%$ & 4 \\
\hline $\begin{array}{l}\text { Woodmere } \\
\text { Elementary }\end{array}$ & $12.8 \%$ & $0.4 \%$ & $-2.2 \%$ & $23.9 \%$ & $19.1 \%$ & -1 \\
\hline $\begin{array}{l}\text { Woodstock } \\
\text { Elementary }\end{array}$ & $7.4 \%$ & $2.8 \%$ & $15.5 \%$ & $46.3 \%$ & $29.6 \%$ & 4 \\
\hline
\end{tabular}

